\title{
UPAYA ORANG TUA DALAM MENINGKATKAN PENDIDIKAN AGAMA ISLAM TERHADAP ANAK DI SDN 08 SENTOSA KECAMATAN DUA KOTO KABUPATEN PASAMAN
}

\author{
Ishardi \\ Universitas Muhammadiyah Sumatera Barat, Padang \\ Email:Ishardi06@gmail.com
}

\begin{abstract}
ABSTRAK
Penelitian ini bertujuan untuk mendeskripsikan tentang upaya orang tua dalam meningkatkan Pendidikan Agama Islam terhadap anak di SDN 08 Sentosa Kecamatan Dua Koto Kabupaten Pasaman. Penelitian ini menggunakan jenis penelitian kualitatif dan menggunakan metode observasi, wawancara dan dokumentasi. Sedangkan analisis data dengan cara mereduksi data, penyajian data, dan membuat kesimpulan. Hasil penelitian menyatakan bahwa pertama: Pengarahan orang tua terhadap anak dapat meningkatkan Pendidikan Agama Islam anak, sebab orang tua adalah peletak landasan pendidikan bagi anak dalam keluarga yang selanjutnya akan menjadi landasan membentuk pribadi anak di hari kemudian. Kedua: kedisiplinan anak untuk belajar di rumah dapat terwujud dengan adanya pengawasan orang tua. Ketiga, untuk mendukung pencapaian Pendidikan Agama Islam anak, peran orang tua dapat memberikan dorongan kepada anak di rumah antara lain memperhatikan proses pembelajaran, memberikan nasehat, memberikan reward, dan hukuman pendidikan, serta memberikan fasilitas belajar anak secara berkelanjutan.
\end{abstract}

Kata Kunci: Upaya Orang Tua, Pendidikan Agama Islam, Anak

\begin{abstract}
This study aims to describe the efforts of parents in improving Islamic religious education for children in SDN 08 Sentosa Kecamatan Dua Koto Kabupaten Pasaman. This research uses qualitative research using observation, interview and documentation methods. While data analysis is by reducing data, presenting data, and making conclusions. The results showed that first: Parental guidance towards children can improve children's Islamic religious education, because parents are the foundations of education for children in the family which will then become the basis for the child's personality in the future. Second: the discipline of children to study at home can be realized with parental supervision. Third, to support the achievement of children's Islamic religious education, the role of parents can encourage children at home including attention to the learning process, giving advice, giving gifts and educational punishments, and providing sustainable children's learning facilities.

Keywords: Parents' Efforts, Islamic Religious Education, Children

\section{Pendahuluan}

Setiap agama mempunyai tujuan, dalam ajaran agama Islam adapun tujuan utama yang harus dicapai ialah kesuksesan di dunia dan kesuksesan di akhirat. Keberhasilan hidup seorang muslim/muslimah di akhirat tentunya tergantung bagaimana kehidupannya di dunia. Sehingga kehidupan di dunia adalah penentu kehidupan manusia kelak di akhirat. Setiap kebaikan yang dilakukan di dunia akan mendapat imbalan di akhirat, demikian sebaliknya setiap keburukan yang dilakukan di dunia tentunya akan mendapat kesengsaraan sebagai gantinya.

Kehidupan yang baik dapat diperoleh melalui pendidikan. Pendidikan
\end{abstract}


mempunyai tiga bidang yakni keluarga, sekolah, dan masyarakat, ${ }^{2}{ }^{2}$ Dari ke tiga lingkungan ini tidak lepas dari pendidikan agama sebagai dasar pada setiap aktifitas yang dilaksanakan. ${ }^{3}$ Karena lingkungan ini lah yang akan memberikan pengaruh terhadap terbentuknya individu yang berakhlak mulia baik secara langsung ataupun tidak langsung. ${ }^{4}$

Kerjasama yang baik dan interaksi yang harmonis antara ketiga lingkungan di atas dapat mewujudkan tujuan pendidikan Islam yang ideal yang terdapat pada Undang-Undang 45 pasal 31 ayat 3 dimana dalam pengembangan kemampuan anak supaya menjadi insan yang memiliki iman dak takwa terhadap Allah SWT, memiliki akhlak mulia, berilmu, sehat, kreatif, berkemampuan, mandiri, serta menjadi warga Negara yang demokratis dan memiliki tanggung jawab. ${ }^{5}$

Tujuan Pendidikan Agama ialah upaya sadar dalam pembentukan insan berakhlak mulia sejalan dengan tujuan Pendidikan Agama Islam, yakni mencerdaskan manusia menjadi manusia yang memiliki nilai moral, menanamkan kebaikan di dalam jiwa mereka, membiasakan mereka untuk mengutamakan rasa sopan yang tinggi, mempersiapkan diri menuju kehidupan yang suci dan ikhlas, serta jujur. ${ }^{6}$

Dalam mencapai tujuan Pendidikan Agama Islam bisa dilaksanakan lewat organisasi formal dan non formal. Sekolah adalah salah satu lembaga formal yang memberikan pembelajaran tentang Pendidikan Agama Islam. Dalam mewujudkan tujuan tersebut sekolah juga menyelenggarakan berbagai kegiatan ektrakurikuler di bidang Agama Islam. Namun demikian, tujuan akan tercapai jika upaya tersebut diselenggarakan secara terpadu antara pihak sekolah, keluarga, dan masyarakat.

Banyak kalangan ahli berpendapat bahwa pendidikan keluarga merupakan awal pendidikan seorang anak yang akan menentukan keberhasilan Pendidikan Agama Islam di sekolah. Selain daripada itu, beberapa ahli lainnya berpendapat bahwa keluarga adalah tiang utama bagi anak-anak yang sedang mengalami perkembangan. ${ }^{7}$ Hal tersebut menunjukkan bahwa orang tua adalah tolak ukur bagi masa depan, orang tualah fundamen keberhasilan di sekolah maupun di masyarakat.

Setiap fase perkembangan anak baik aspek jasmani, aspek intelektual, aspek fantasi serta perasaan dan moral anak akan selalu mempengaruhi perkembangan

1 Subianto, J. Peran Keluarga, Sekolah, dan Masyarakat dalam Pembentukan Karakter Berkualitas. Edukasia: Jurnal Penelitian Pendidikan Islam, 2013. 8(2), h.331-354.

${ }^{2}$ Hidayati, N. Konsep Integrasi Tripusat Pendidikan Terhadap Kemajuan Masyarakat. Edukasia: Jurnal Penelitian Pendidikan Islam, 2016. 11(1), h.203-224.

3 Anisa. Pengarub Tri Pusat Pendidikan terhadap Pembentukan Karakter Religius Peserta Dididk di SD Islam As-Salam dan SD Islam Daarul Fikri Malang. Universitas Islam Negeri Maulana Malik Ibrahim, 2018.

${ }^{4}$ Ritonga, dkk. Madrasah al-Ula for Children: An Effective Learning Management in the Family during Covid-19 Pandemic. Ilkogretim Online - Elementary Education Online, 2021, 20(1), h.968-976.

5 Awwaliya. dkk. Pendidikan Islam dalam Sistem Pendidikan Nasional (Telaah Epistemologi terhadap Problematika Pendidikan Islam). Pendidikan Islam Dalam Sistem Pendidikan Nasional (Telaah Epistemologi Terhadap Problematika Pendidikan Islam), 2018. 19(1), h. 34-49.

'Wahid, A. Konsep dan tujuan pendidikan Islam. ISTIQRA', III(1), 2015. h. 18-23.

7 Wulandari, dkk. Analysis of Life-Course Factors Influencing Growth and Development in Children under 3 Years Old of Early Marriage Women in Kediri. Journal of Maternal and Child Health, 2017. 2(2), h.137-149. 
anak pada fase selanjutnya, ${ }^{9}$ ' Apabila orang tua tidak bisa membentuk anak maka lingkungannyalah yang akan membentuknya. Orang tua yang terbiasa membantu anak untuk dewasa tentunya tidak sama dengan orang tua yang tidak peduli. Peran orang tua tidak dapat digantikan karena demikian pentingnya bagi anak oleh sebab itu Nabi Muhammad SAW menuangkan nasehat, petunjuk, serta pelajaran bagi umatnya.

Apabila orang tua tidak bisa membentuk anaknya maka lingkungannyalah yang akan membentuknya. Upaya orang tua dalam membantu anaknya untuk berprestasi tentu akan berbeda dengan yang membiarkan anaknya. Yang terbiasa dengan pengaruh positif seperti membaca al-Quran, rajin belajar, shalat berjama'ah, bangun tepat waktu, penuh daya saing, perhatian, disiplin dan yang lainnya tentu akan berbeda hasilnya dengan orang tua yang terbiasa malas membaca, melalaikan sholat, sering santai, tidak disiplin atau sibuk diluar tanpa pernah tahu keadaan belajar anak.

Sementara itu orang tua merupakan pendidik yang mempunyai fungsi sebagai landasan dalam pendidikan moral serta agama anak baik dalam pendidikan sosial maupun pendidikan moral. Hal paling mendasar dari orang tua adalah kasih sayang dan bagaimana kedudukan anak dalam keluarga. Namun jika usaha pendidikan dalam keluarga tersebut gagal, maka akan terbentuklah anak yang cenderung tidak rajin, maka nilai anak tidak sesuai dengan keinginan orangtuanya.

Pencapaian prestasi sesuai dengan harapan tidaklah mudah, karena dipengaruhi oleh berbagai faktor, ada sumbernya dari diri anak sendiri ada juga yang dari luar diri anak. Di antara faktor itu berpengaruh terhadap prestasi belajar anak seperti jasmani, lingkungan keagamaan, lingkungan fisik, lingkungan sosial, yaitu lingkungan tempat anak tinggal. Ketersediaan fasilitas belajar dan orang tua yang terlibat dalam membimbing dan membantu kesulitan belajar anak mempunyai pengaruh yang tinggi terhadap menentukan keberhasilan dan keberhasilan akademik anak.

Berdasarkan wawancara penulis dengan pihak sekolah yaitu Ibu Maihenis, S.Pd selaku kepala SDN 08 Sentosa Kecamatan Dua Koto Kabupaten Pasaman yang menyatakan bahwa berbagai upaya telah dilakukan pihak sekolah untuk meningkatkan pendidikan agama Islam pada anak, namun belum terwujud seutuhnya karena belum adanya kerjasama dan upaya orang tua secara maksimal. Dalam upaya menumbuhkembangkan potensi anak maka SDN 08 Sentosa Kecamatan Dua Koto Kabupaten Pasaman memfasilitasi anak dengan kegiatan ekstrakurikuler, salah satunya adalah tahfidz. Dalam pelaksanaan kegiatan ini hendaknya tidak lepas dari arahan dan pengawasan dari orang tua agar prosenya berjalan lancar dan hasilnya sesuai dengan harapan.

Hal ini sejalan dengan wawancara penulis dengan Ibu Eli Asnimar, S.Pd.I menjabat sebagai guru Pendidikan Agama Islam di SDN 08 Sentosa Kecamatan Dua Koto Kabupaten Pasaman yang menyatakan bahwa bimbingan dan pengawasan mempengaruhi hasil belajar pendidikan agama Islam anak. Prestasi belajar diperoleh anak

\footnotetext{
${ }^{8}$ Garrigan, dkk. Moral decision-making and moral development: Toward an integrative framework. Developmental Review, 49(March, 2016), h. 80-100.

${ }^{9}$ Darling-churchill, dkk. Early childhood social and emotional development : Advancing the fi eld of measurement. Journal of Applied Developmental Psychology, 45. 2016, h. 1-7.
} 
sangat dipengaruhi oleh upaya orang tua membantu membimbing anak untuk belajar. Dugaan tersebut berdasarkan pernyataan beberapa orang anak berprestasi menyatakan bahwa orang tua mereka mengawasi dan membantu mengatasi kesulitan belajar mereka di rumah.

Kehidupan orang tua anak di lingkungan SDN 08 Sentosa Kecamatan Dua Koto Kabupaten Pasaman pada umumnya dalam hal bekerja untuk memenuhi kebutuhan keluarga bukan sekedar laki-laki saja. Hal ini disebabkan tuntutan ekonomi yang menuntut perempuan juga mencari nafkah guna untuk dapat memenuhi kebutuhan. Tidak jarang kedua orang tua sibuk bekerja seharian sehingga pada saat sampai di rumah semuanya sudah lelah. Situasi inilah yang terkadang membuat mereka memenuhi kebutuhan anaknya hanya dari segi kelahiran, seperti sandang, pangan, dan papan.

Hasil wawancara yang penulis lakukan terhadap tiga keluarga dengan latar belakang berbeda menyatakan bahwa kesibukan orang tua secara pribadilah yang menjadikan komunikasi orang tua dengan anak tidak berjalan dengan baik. Sehingga minimnya bimbingan berpengaruh terhadap pendidikan agama Islam anak. Kesadaran orang tua sebagai penanggung jawab terhadap anak sangat diharapkan untuk mengembangkan aspek positif pada diri anak salah satunya adalah meningkatkan pendidikan agama Islam anak.

Dari pembahasan bersama orang tua peserta didik menyatakan bimbingan orang tua yang paling intensif adalah pada masa perkembangan anak di Sekolah Dasar. Oleh karena itu arahan, pengawasan, dorongan, serta teladan orang tua diharapkan untuk perkembangan yang terbaik pada saat mencapai tujuan yang diinginkan.

Begitu penting upaya meningkatkan Pendidikan Agama Islam anak, oleh karena itu yang menjadi fokus penelitian adalah:1)Pengarahan orang tua dalam meningkatkan Pendidikan Agama Islam terhadap anak di SDN 08 Sentosa Kecamatan Dua Koto Kabupaten Pasaman, 2) Pengawasan orang tua dalam meningkatkan Pendidikan Agama Islam terhadap anak di SDN 08 Sentosa Kecamatan Dua Koto Kabupaten Pasaman, 3) Dorongan orang tua dalam meningkatkan Pendidikan Agama Islam terhadap anak di SDN 08 Sentosa Kecamatan Dua Koto Kabupaten Pasaman.

\section{METODE PENELITIAN}

Tempat melakukan penelitian ialah di SDN 08 Sentosa Kecamatan Dua Koto Kabupaten Pasaman, dimana sekolah ini terletak di jorong sentosa kecamatan dua Koto Kabupaten Pasaman Provinsi Sumatera Barat. Jenis penelitian adalah penelitian kualitatif. Sementara itu, untuk menganalisis data penelitian ini, digunakan pendekatan deskriptif, termasuk ekspresi tertulis atau lisan masyarakat dan tindakan yang bisa diamati.

Dalam penelitian ini pengumpulan data yang dilakukan adalah dengan teknik observasi, wawancara dan dokumentasi. Yang diobservasi adalah Guru Pendidikan Agama Islam SDN 08 Sentosa Kecamatan Dua Koto Kabupaten Pasaman dan orangtua peserta didik SDN 08 Sentosa Kecamatan Dua Koto Kabupaten Pasaman. Yang 
diwawancarai ialah Kepala Sekolah, Guru Pendidikan Agama Islam serta orang tua Peserta Didik SDN 08 Sentosa Kecamatan Dua Koto Kabupaten Pasaman. Adapun dokumentasi berupa data sekolah serta data peserta didik serta foto-foto kegiatan maupun foto-foto dokumentasi yang mendukung penelitian.

Analisis data adalah proses pengorganisasian dan pengelompokan data ke dalam pola, kategori, dan deskripsi unit dasar sehingga topik dapat ditemukan dan hipotesis yang layak dapat dirumuskan berdasarkan rekomendasi data. Sehubungan dengan itu, data yang diperoleh melalui observasi dan wawancara dianalisis untuk memastikan Upaya Orang Tua Meningkatkan Pendidikan Agama Islam di SDN 08 Sentosa Kecamatan Dua Koto Kabupaten Pasaman.

\section{HASIL PENELITIAN DAN PEMBAHASAN}

Sebagai orang tua, mendidik anak-anaknya merupakan tuntunan sosial dan kewajibannya. Setiap orang tua mempunyai keinginan untuk memiliki kedudukan yang terhormat di mata orang lain karena setiap individu menyadari bahwa kedudukan terhormat merupakan kebutuhan naluriah setiap insan.

Kewajiban mendidik anak telah disadari oleh para orang tua bahwa diri mereka mempunyai kemampuan yang terbatas dalam mendidik anak-anaknya secara layak. Oleh sebab itu kemampuan orang tua yang terbatas telah mengharuskan mereka untuk bekerja sama dengan berbagai pihak yaitu dengan lembaga pendidikan dan masyarakatnya. Kewajiban terbesar bagi orang tua adalah mendidik anaknya yang diamanatkan oleh Allah SWT. Orang tua tidak boleh lepas dari tanggung jawab karena orang tualah yang menghendaki anaknya dilahirkan, ${ }^{10}$ oleh sebab itu mereka jugalah yang harus mendidiknya agar anaknya mampu menjadi generasi baru yang lebih berkualitas dan mandiri di kemudian hari. ${ }^{11}$

Orang tua merupakan dasar-dasar terbentuknya pola pikir anak, dan menjadi fundamen bagi kehidupan anak selanjutnya. Situasi emosional anak erat kaitannya dengan pendidikan awal yang diterima anak dari orang tuanya karena orang tua merupakan kontributor terbesar dalam membentuk emosional anak.

Di lingkungan rumah orang tua dapat berperan sebagai guru, teman, dan juga motivator. Orang yang pertama memberikan pelajaran berharga kepada anak adalah orang tua. Kehangatan, cinta, kedamaian, senyuman dapat dirasakan anak dari orang tuanya. Sebuah pernyataan menggambarkan, "orang tua merupakan madrasah bagi putraputrinya. Jika orang tua mempersiapkan putra putrinya dengan baik, maka akan sama dengan mempersiapkan pokok pangkal bangsa yang baik pula."12

Lingkungan keluarga merupakan salah satu lingkungan sosial terdekat bagi anak. Kebiasaan-kebiasaan anak dalam menjalankan aktivitasnya seperti halnya belajar akan bermula dari lingkungan keluarganya. Kebiasaan belajar yang efektif atau tidak juga

${ }^{10}$ Ceka, dkk. The Role of Parents in the Education of Children. Journal of Education and Practice, 2016. 7(5), h. 61-64.

${ }^{11}$ Sapungan, dkk. Parental Involvement in Child's Education : Importance, Barriers and Benefits. Asian Journal of Management Sciences \& Education, 2015. 3(2), h. 42-48.

12 Ritonga, dkk. Madrasah al-Ula for Children: An Effective Learning Management in the Family during Covid-19 Pandemic. Ilkogretim Online - Elementary Education Online, 2021. 20(1), h. 968-976. 
diawali oleh pembinaan keluarga. Perhatian tinggi terhadap anak mulai dari hal-hal terkecil dari diri anak haruslah menjadi perhatian bagi orang tua, permasalahpermasalahan yang dihadapi anak dan memenuhi kebutuhan anak.

Kondisi keharmonisan lingkungan keluarga juga diduga memberikan pengaruh besar terhadap aktivitas belajar anak beserta keberhasilannya. Keluarga yang harmonis, tentu dapat mendukung lancarnya aktivitas belajar anak. Adanya percekcokan yang sering terjadi di keluarga akan cenderung menghambat kelancarannya belajar anak. Keluarga yang broken home biasanya menciptakan kegalauan anak sehingga tidak dapat konsentrasi belajar baik dirumah maupun di kelas. Bahkan, hal tersebut dapat menciptakan rasa malu anak dan malas ke sekolah.

Orang tua penanggung jawab tentang semua yang berhubungan terhadap anakanaknya. Baik dari segi pendidikan maupun kelangsungan hidup anak-anaknya untuk masa saat ini maupun yang akan datang. Peran orang tua sangat penting dan paling besar pengaruhnya terhadap pendidikan. Karena tanggung jawab tersebut disadari atau tidak disadari oleh orang tua, maka tetap merupakan 'yang nyaman bagi anaknya dalam proses pembelajaran. Segala kekurangan dan kesulitan anak dapat diketahui oleh orang tua melalui bimbingan terhadap anak oleh sebab itulah bimbingan orang tua mutlak dibutuhkan ketika berada di rumah. Dengan mengetahui kekurangan dan kesulitan anak orang tua dapat mengetahui pengarahan yang bagaimana yang dapat diberikan kepada anak sebagai bukti kepedulian terhadap anak. Perbedaan karakteristik anak dan perbedaan kemampuan anak akan mempengaruhi cara pengarahan yang akan diberikan oleh orang tuanya di rumah.

Mengikutsertakan pembiasaan adalah cara orang tua melakukannya agar mengarahkan anak berperilaku Islami seperti pembiasaan akhlak yang baik, bertutur kata sopan, dan menghormati orang lain. Kebiasaan anak di rumah akan terbawa ke sekolah. Hal ini tentunya dapat meningkatkan pendidikan anak di sekolah

Pernyataan orang tua menyatakan bahwa wajib bagi orang tua menjadi suri tauladan untuk anak perihal menanamkan nilai-nilai agama Islam. Tujuannya adalah dalam kehidupannya anak mencontohkan perilaku orang tuanya.

Diperlukan sikap ketegasan dari orang tua untuk memberikan pengarahan terhadap anak untuk belajar. Sikap acuh tak acuh terhadap pendidikan anak akan membawa anak pada suatu kegagalan. Pengarahan orang tua berdampak pada sikap anak, tinggi rendahnya perhatian orang tua mempengaruhi sikap anak.

Komunikasi sehari-hari sangat penting untuk mengungkapkan pengawasan terhadap anak. Komunikasi positif akan menumbuhkan keakraban diantara orang tua dengan anak dan sebaliknya jika komunikasi kurang baik akan menimbulkan pengaruh yang buruk bagi anak. Oleh sebab itu, untuk menunjang perkembangan anak maka orang tua harus memberikan pengawasan kepada anak, cara yang paling relevan yang ditempuh orang tua adalah dengan sering berkomunikasi dengan anak di rumah hal ini juga akan mengesankan bagi baik pada anak karena selalu diperhatikan oleh orang tuanya Mempelajari pendidikan agama sedini mungkin merupakan suatu hal yang sangat penting mengingat pendidikan agama mampu menjadi benteng yang kokoh bagi anak yang terkadang dengan mudah sekali jatuh ke dalam kesesatan. 
Melihat ungkapan orang tua bahwa sesibuk apapun bekerja hendaklah dapat meluangkan waktu untuk mengawasi anaknya agar pendidikan agama Islam meningkat. Karena dapat dipahami orang tua adalah pendidik terdepan yang akan mengingatkan anak-anaknya untuk selalu belajar dengan giat lalu mengamalkannya. Pengawasan sangat diperlukan dalam meningkatkan pendidikan agama Islam. Orang tua senantiasa bertanya tentang aktifitas anaknya di sekolah adalah salah satu sikap orang tua yang mencerminkan kepeduliannya kepada anak agar mampu mengetahui perkembangan anaknya. Penulis mengambil kesimpulan bahwa pengawasan orang tua memberikan dampak yang sangat besar terhadap pendidikan agama Islam. Perhatian dan bimbingan, keakraban hubungan dengan anak-anak juga turut memberikan dampak terhadap pencapaian prestasi anak.

Pengawasan sangat penting dalam meningkatkan pendidikan agama Islam. seorang anak dapat menunjukkan bakatnya dan mengikuti pendidikan dengan pengawasan orang tua. Pengawasan orang tua tentang kedisiplinan anak dalam belajar harus selalu ditingkatkan. Pengawasan tersebut harus kuat serta hanya bertujuan untuk kegiatan pendidikan. Ikatan emosional antara anak dengan orang tua harus disatukan agar situasi yang diharapkan dapat tercipta. Anak akan meningkatkan perkembangan diri mereka menuju kehidupan yang sukses jika anak berada pada suasana yang aman lagi nyaman.

Pengawasan orang tua sangat berpengaruh terhadap psikologis anak dalam mengikuti pembelajaran agama Islam. Pengawasan orang tua membuat anak penuh semangat karena anak menyadari yang berkeinginan untuk maju bukanlah dirinya sendiri, namun orang tuanya juga demikian. Semakin besar partisipasi orang tua dalam memberikan pengawasan akan semakin tinggi tingkat antusiasme anak untuk meningkatkan pendidikan agamanya. Demikian pentingnya upaya orang tua, oleh sebab itu pihak sekolah harus lebih meningkatkan komunikasi dan kerjasama dengan orang tua untuk meningkatkan pendidikan agama Islam anak di SD N 08 Sentosa Kecamatan Duo Koto Kabupaten Pasaman.

Keterlibatan langsung orang tua dalam pendidikan anaknya sangatlah diperlukan terutama mengenai dorongan. Bentuk dorongan, misalkan bentuk pujian, memberikan semangat kepada anaknya dan juga senantiasa memberikan teguran kepada anak jika bermalas-malasan dalam belajar. Dalam usia anak yang masih dalam kategori masih labil dorongan orang tua mutlak diperlukan adanya, termasuk ketika anak mendapat nilai yang jelek, maka orang tua hendaknya memberikan dorongan agar anak belajar lebih baik lagi dan melakukan konsultasi dengan guru.

Hasil wawancara dengan orang tua peserta didik diambil sebuah gambaran umum bahwa anak akan lebih termotivasi dalam belajar jika mendapatkan penghargaan dari orang tuanya. Bentuk perhatian ini tentunya akan berdampak baik bagi perkembangan anak, hal tersebut dapat meningkatkan dorongan bagi anak dalam meningkatkan kemampuannya. Namun demikian orang tua juga memberikan hukuman yang mendidik jika hasil belajar anak rendah .

Hal ini sesuai dengan yang penulis lihat pada saat penulis mengunjungi rumah pak Sofyan Husni. Anaknya bernama Ahmad Yusuf. Tidak lama kemudian azan ashar 
berkumandang, penulis melihat anaknya pulang bermain dan membersihkan diri. Hal ini rutin dilakukan oleh anaknya, anaknya akan pulang jika mendengar suara azan, ternyata batas bermain anaknya di luar rumah adalah hingga waktu ashar dan Kedisiplinan anaknya adalah hasil dari kesabaran dan ketekunan orang tuanya yang tidak pernah bosan untuk membimbing anaknya.

Hasil penuturan beberapa orang tua dari anak di SDN 08 Sentosa Kecamatan Dua Koto Kabupaten Pasaman disimpulkan dimana hampir semua orang tua mengatakan, dorongan sangat memegang peran penting demi peningkatan prestasi. Masa depan setiap anak merupakan tanggung jawab orang tuanya. Tidak ada orang lain yang bertanggung jawab secara penuh terhadap anak selain dari orang tua. Orang tualah yang mempunyai kewajiban untuk membina anak supaya menjadi insan berguna bagi agama juga bangsa. Pendidikan dari orang tua akan seiring dengan pembelajaran anak di sekolah.

Tanggung jawab orang tua bukan sekedar memilihkan sekolahdan memenuhi semua kebutuhan anak. Selain daripada itu, orang tua yang tanggung jawab akan terlibat langsung dalam pendidikan (kehidupan) anak. Perbuatan baik orang tua merupakan keterlibatan secara alami bagi kehidupan dan pendidikan anak. Lebih dari itu, tanggung jawab orang tua adalah keterlibatan langsung orang tua dalam pendidikan (kehidupan) anaknya. Perlakuan yang baik dari orang tua kepada anak adalah keterlibatan langsung orang tua dalam kehidupan dan pendidikan anak

Apabila orang tua sungguh-sungguh memberikan dorongan kepada anaknya dengan tepat, benar, dan disesuaikan dengan pertumbuhan dan perkembangan anak serta dengan ikhlas dan penuh rasa sabar, telaten dan tanggung jawab yang tinggi maka prestasi pembelajaran anak dalam pendidikan agama Islam di SDN 08 Sentosa Kecamatan Dua Koto Kabupaten Pasaman dapat dicapai dengan hasil yang memuaskan. Prestasi belajar anak biasanya dilakukan dengan pengukuran melaui tes atau ujian yang diberikan pendidik. Prestasi anak adalah kecakapan anak dalam serangkaian ilmu pengetahuan yang telah dimiliki oleh anak.

Setiap keluarga dalam hal memelihara dan memberi bimbingan tentunya memiliki teknik tersendiri. Teknik tersebut pasti tidak sama antara pada setiap keluarga. Hal ini menunjukkan bagaimana tingkah laku orang tua saat berkomunikasi dengan anaknya, demikian juga dalam berkomunikasi selama membimbing anak. Berbagai cara dapat diperbuat orang tua dalam memberi bimbingan contohnya berilah perhatian, menegakkan aturan, mengatur kedisiplinan diri anak, memberi hadiah jika anak berperilaku baik dan memberik hukuman ketika anak berperilaku buruk, serta menanggapi setiap perlakuan anak. Dengan demikian semangat anak dalam belajar akan semakin tinggi dan anak meraih prestasi unggul.

Dorongan memang sangat berpengaruh terhadap pendidikan agama Islam anak, karena dapat membuat anak menyadari tugas dan tanggung jawabnya. Selain itu, rasa nyaman pada diri anak jika orang tua selalu bersamanya ketika belajar dan memperhatikan semua kebutuhannya. Besarnya peran orang tua dalam memberi pendidikan, bimbingan, penyediaan kebutuhan belajar untuk anak dan menjadi figur yang baik bagi anak. 


\section{PEMBAHASAN}

Orang tua peserta didik SDN 08 Sentosa Dua Koto Kabupaten Pasaman seluruhnya menganut agama Islam, dimana setiap orang tua tentunya mempunyai kewajiban menyediakan pendidikan tentang ajaran Islam bagi anaknya. Keikut sertaan orang tua dalam Pendidikan ditanamkan sejak dini dalam keluarga ialah tuntunan yang harus dipatuhi. Allah SWT berfirman dalam Al Quran Surat At Tahrim ( Surat 66: ayat 6)

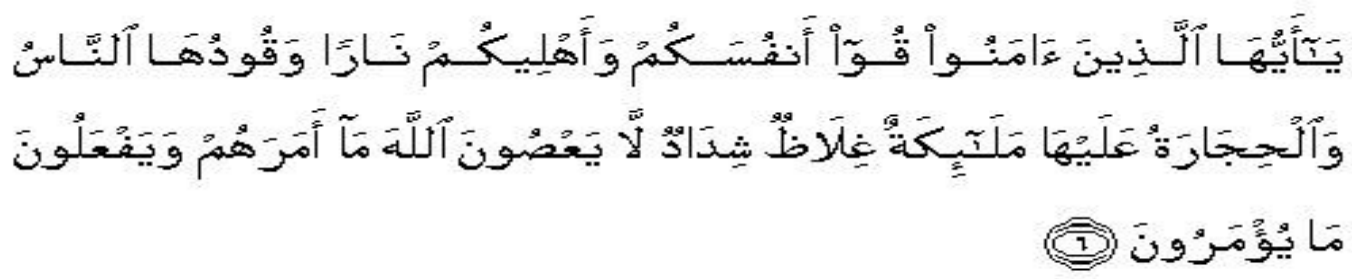

\section{Artinya : Hai orang-orang yang beriman, peliharalah dirimu dan keluargamu dari api neraka yang bahan bakarnya adalah manusia dan batu; penjaganya malaikat-malaikat yang kasar, keras, dan tidak mendurhakai Allah terhadap apa yang diperintahkan-Nya kepada mereka dan selalu mengerjakan apa yang diperintahkan}

Jika dilihat dari data tentang kategori upaya orang tua terhadap seluruh orang tua, anak yang telah diwawancarai maka semuanya menunjukkan bahwa pengarahan yang baik dari orang tua memberikan dampak positif terhadap peningkatan pendidikan agama anak di sekolah, misalnya apabila anak belum belajar di rumah maka orang tuanya selalu memberi pengarahan, apabila anak tidak mengalami kesulitan maka orang tua memberi bantuan, apabila anak belum paham maka orang tua memberikan penjelasan, orang tua harus memberi arahan terhadap anak untuk tidak cepat puas dalam pencapaian hasil belajarnya dan tidak berputus asa jika mengalami kesulitan.

Pengarahan orang tua dalam mengarahkan anak untuk meningkatkan pendidikan agama sangatlah urgen. Selanjutnya menggabungkan pemikiran dan pendapat antara orang tua dengan guru (dapat dilakukan melalui parenting) tentang kebutuhan pendidikan agama anak. Ketika anak berada di lingkungan rumah bersama orang tuanya maka akan terbentuk akhlaq dan agama anak sesuai dengan lingkungannya dan ketika anak berada di lingkungan sekolahnya akan terbentuk akhlaq dan agama anak sesuai dengan lingkungan sekolahnya. Oleh sebab itu penerapan pembelajaran untuk pembiasaan akhlaq harus sejalan antara lingkungan rumah dengan sekolah. Misalnya pembiasaan membaca doa ketika sebelum atau sesudah melakukan kegiatan, pembiasaan mengucapkan kalimat-kalimat thayyibah dalam setiap keadaan, bersikap sopan dan santun terhadap semua orang. Semua pembiasaan di sekolah hendaknya diterapkan di rumah. Meskipun keluarga adalah aspek yang sejak dini menanamkan sendi-sendi kehidupan untuk masa depan anak namun tetap selalu membutuhkan orang lain untuk memberikan arahan, bimbingan, dan pedoman hidup ke depan untuk anak-anaknya.

Semakin hari tantangan dan godaan semakin banyak, gelombang tantangan 
kehidupan saling berbenturan, dan tersedianya berbagai media yang dapat merusak anak jika salah dalam penggunaannya. Dimana teknologi semakin canggih yang dapat merusak mental anak jika tidak mendapat pengawasan penuh dari orang tua. Pengaruh dari orang tua merupakan 'illah tāmmah (penyebab lengkap) masa depan anak mengarah pada kebahagiaaan atau kesengsaraan. Orang tua harus mempunyai komitmen terhadap aturan Islam, orang tua harus mempersiapkan anak supaya bisa tumbuh dengan perilaku yang mulia dan diberkati sehingga mendapat kemaslahatan dan kebahagiaan. Maka jika orang tua mengabaikan komitmen terhadap norma-norma Islam dan hukum-hukum Islam akan tercipta lahan yang subur bagi tumbuh kembang anak yang mengarah pada kesengsaraan.

Jika pendidikan seorang anak terbengkalai maka yang rugi bukan sekedar dirinya sendiri, tetapi juga lingkungan dalam kehidupannya. Maka untuk menguatkan disiplin agar pendidikan anak tidak terbengkalai dibutuhkan pengawasan dari orang tua. Bentuk pengawasan dari orang tua dapat berupa menjadwalkan kegiatan belajar anak di rumah, mengecek apakah tugas anak sudah selesai, menanyakan kesulitan-kesulitan belajar anak, bertanya kepada guru tentang peningkatan belajar anak di sekolah, memeriksa hasil belajar anak, dan mengontrol anak dalam menggunakan media sosial.

Inti kesuksesan anak di dalam rumah tangga dan masyarakat adalah pendidikan dari orang tua. Orang tua memberikan pengaruh yang terkuat dalam kehidupan anak. Butuh waktu yang cukup panjang untuk mencapai target pendidikan dan harus dimulai dari usia dini. Pendidikan agama merupakan hakikat atau dasar dari segala kebaikan yang tertanam dalam diri manusia untuk menjadi pribadi muslim yang sholih dan sholihah maka harus dijalani dengan mujahadah atau kesungguhan yang terus menerus.

Dari segi dorongan orang tua terhadap belajar anak di rumah, berdasarkan wawancara terhadap seluruh responden menyatakan bahwa ketika anak mereka akan menghadapi ujian kebanyakan orang tua mereka selalu mengawasinya agar selalu belajar, setiap kali ada pembagian rapot mereka selalu memeriksanya. Jika anak memperoleh nilai yang memuaskan maka orang tua senantiasa memberikan pujian bahkan hadiah. Hal ini menunjukkan orang tua mereka penuh perhatian dan mendorong anak-anaknya dengan baik agar selalu belajar di rumah.

Untuk mencapai kesuksesan dalam segala hal, maka pada hakikatnya sangat membutuhkan motivasi atau dorongan yang dapat terus memberi semangat pada seseorang. Tentunya motivasi ini bisa datang dari diri sendiri atau orang lain. Motivasi dari diri tumbuh dari adanya keinginan untuk meraih sesuatu sehingga seseorang melakukan segala upaya untuk meraih hal tersebut. Sedangkan motivasi dari luar berasal dari dorongan yang diberikan oleh orang lain kepada dirinya sebagai bentuk dukungan dan perhatian kepadanya. Motivasi orang tua kepada anak mengenai belajar merupakan suatu motivasi yang bertujuan memberikan dukungan kepada anak agar anak selalu merasa semangat dalam belajar. Motivasi orang tua kepada anak juga adalah bentuk perhatian dan rasa peduli orang tua kepada anak terutama dalam perkembangan belajarnya. Melalui motivasi, orang tua berharap agar anaknya kelak dapat lebih giat belajar dalam meraih cita-cita yang diinginkannya dan menjadi pribadi yang berguna bagi masyarakat banyak.

Dari hasil observasi yang dilakukan penulis kepada orang tua peserta didik di 
SDN 08 SDN 08 Sentosa Kecamatan Dua Koto Kabupaten Pasaman ditemukan bahwa dengan dorongan orang tua terlihat bahwa anak menjadi dekat dan terbuka dengan orang tua. Hal ini dapat diamati dari perilaku anak saat berada di dekat orang tuanya. Selain hasil dari observasi yang dilakukan terhadap orang tua peserta didik di SDN 08 Sentosa Kecamatan Dua Koto Kabupaten Pasaman hasil wawancara yang penulis lakukan juga menunjukkan bahwa orang tua berpendapat dengan adanya pemberian dorongaan belajar kepada anak membuat anak lebih bersemangat dan merasa jauh lebih bergairah dalam belajar. Beberapa orang tua mengatakan bahwa dengan memberikan dorongan belajar kepada anak, mereka justru menjadi lebih rajin belajar. Di samping itu, anak-anak menjadi lebih penurut dan mendengar nasihat orang tua khususnya dalam hal belajar. Anak menjadi gemar belajar khususnya dalam mengerjakan pekerjaan rumah dengan didampingi oleh orang tuanya. Tidak hanya itu saja, dengan pemberian motivasi seperti memenuhi peralatan-peralatan sekolah yang diperlukannya membuat anak selalu menceritakan kondisi belajarnya di sekolah maupun permasalahan-permasalahan yang dihadapinya di sekolah.

Dengan demikian, pemberian dorongan oleh orang tua kepada anak menunjukkan respon yang baik Pada hasil wawancara menunjukkan bahwa dari 10 kepala keluarga yang menjadi subjek penelitian mengatakan bahwa motivasi dapat meningkatkan pendidikan agama Islam anak.

Selain itu, kadang kala anak jauh lebih bersemangat dalam belajar apabila orang tua memberikan hadiah sehingga ia menjadi lebih terbuka dengan orang tua dan cenderung mendengarkan nasihat atau mematuhi perintah orang tuanya. Pada kenyataannya, pemberian motivasi belajar kepada anak tidak hanya meningkatkan semangat belajar, akan tetapi juga berpengaruh positif terhadap prestasinya dalam pendidikan agama Islam.

Penulis menemukan berbagai cara dilakukan orang tua dalam memberikan pengarahan, pengawasan, dan dorongan yang mana dari semua itu tujuannya meningkatkan pendidikan anak. Demikianlah hendaknya kesadaran setiap orang tua untuk senantiasa berupaya untuk mewujudkan harapan bersama yaitu meningkatkan pendidikan agama Islam anak di SDN 08 Sentosa Kecamatan Duo Koto Kabupaten Pasaman.

\section{KESIMPULAN}

Orang tua bisa memberi perhatian terhadap anak dengan berbagai bentuk, misalnya memberikan bimbingan dan nasihat, mengawasi anak belajar, memotivasi anak dan memberikan reward, serta memenuhi fasilitas belajar anak. Bimbingan dan nasihat dari orang tua akan menjadikan anak idealisme, mengawasi anak dapat melatih anak untuk disiplin, presiasi dari orang tua dapat mendorong anak meraih prestasi, serta melengkapi fasilitas belajar anak akan membuat anak teguh pendirian tentang cita-cita dengan memanfaatkan fasilitas yang ada. Upaya orang tua di SDN 08 Sentosa Kecamatan Dua Koto Kabupaten Pasaman yaitu dengan cara selalu memberikan pengarahan, pengawasan dan dorongan terhadap anak. Perhatian orang tua terhadap anak di lingkungan rumah, memotivasi anak untuk rajin dan bergairah untuk belajar karena anak merasa yang berkeinginan untuk maju bukan hanya dirinya sendiri, demikian 
juga dengan orang tuanya.

Keterlibatan orang tua sangat besar artinya untuk memotivasi anak dalam pembelajaran karena orang tua adalah pendiri landasan pendidikan anak sejak dini dan terus menjadi landasan pembentukan pribadi anak di masa depan. Oleh karena itu, hasil belajar yang diraih anak lebih baik karena adanya memotivasi dari orang tua. Prestasi pendidikan agama Islam anak dapat diketahui melalui serangkaian ujian, baik pengetahuan, keterampilan, dan sikap anak. Untuk mendukung pencapaian prestasi pendidikan agama Islam tersebut, maka upaya orang tua untuk dapat meningkatkan pendidikan agama Islam anak antara lain perhatian pada proses pembelajaran, pemberian nasihat, pemberian reward, dan sanksi pendidikan, serta pemberian fasilitas belajar anak sesuai dengan kebutuhannya secara berkelanjutan.

\section{REFERENSI}

Anisa. (2018). Pengarub Tri Pusat Pendidikan terhadap Pembentukan Karakter Religius Peserta Dididk di SD Islam As-Salam dan SD Islam Daarul Fikri Malang. Universitas Islam Negeri Maulana Malik Ibrahim.

Awwaliyah, R., \& Baharun, H. (2018). Pendidikan Islam dalam Sistem Pendidikan Nasional (Telaah Epistemologi terhadap Problematika Pendidikan Islam). Pendidikan Islam Dalam Sistem Pendidikan Nasional (Telaah Epistemologi Terhadap Problematika Pendidikan Islam), 19(1).

Ceka, A., \& Murati, R. (2016). The Role of Parents in the Education of Children. Journal of Education and Practice, 7(5).

Darling-churchill, K. E., \& Lippman, L. (2016). Early childhood social and emotional development: Advancing the fi eld of measurement. Journal of Applied Developmental Psychology, 45. https://doi.org/10.1016/j.appdev.2016.02.002

Garrigan, B., Adlam, A. L. R., \& Langdon, P. E. (2018). Moral decision-making and moral development: Toward an integrative framework. Developmental Review, 49(March). https://doi.org/10.1016/j.dr.2018.06.001

Hidayati, N. (2016). Konsep Integrasi Tripusat Pendidikan Terhadap Kemajuan Masyarakat. Edukasia: Jurnal Penelitian Pendidikan Islam, $11(1)$.

Ritonga, M., Sartika, F., \& Kustati, M. (2021). Madrasah al-Ula for Children: An Effective Learning Management in the Family during Covid-19 Pandemic. Ilkogretim Online - Elementary Education Online, 20(1), 968-976. https://doi.org/10.17051/ilkonline.2021.01.97

Sapungan, G. M., \& Sapungan, R. M. (2015). Parental Involvement in Child 's Education: Importance, Barriers and Benefits. Asian Journal of Management Sciences \& Education, 3(2).

Subianto, J. (2013). Peran Keluarga, Sekolah, dan Masyarakat dalam Pembentukan Karakter Berkualitas. Edukasia: Jurnal Penelitian Pendidikan Islam, 8(2).

Wahid, A. (2015). Konsep dan tujuan pendidikan Islam. ISTIQRA', III(1).

Wulandari, U. R., Budihastuti, U. R., \& Pamungkasari, E. P. (2017). Analysis of LifeCourse Factors Influencing Growth and Development in Children under 3 Years Old of Early Marriage Women in Kediri. Journal of Maternal and Child Health, 2(2). 